\title{
Effect of Season on Growth, Productivity, and Postharvest Quality of Baby Spinach
}

\author{
Ambani R. Mudau \\ Department of Life and Consumer Sciences, University of South Africa, \\ Private Bag X6, Florida, 1710, South Africa
}

\author{
Puffy Soundy \\ Department of Crop Sciences, Tshwane University of Technology, Private \\ Bag X680, Pretoria, 0001, South Africa
}

Hintsa T. Araya

ARC-Roodeplaat Vegetable and Ornamental Plant Institute, Private Bag X293, Pretoria, 0001, South Africa

\section{Fhatuwani N. Mudau' \\ Department of Agriculture and Animal Health, University of South Africa, Private Bag X6, Florida, 1710, South Africa}

Additional index words. Spinacia oleracea, green leafy vegetable, total antioxidant activity, postharvest storage

\begin{abstract}
Spinach is an annual, cool-season, green leafy vegetable that in temperate areas can be grown year-round. However, different seasons can influence the quality and shelf life of the produce. The objective of this study was to investigate the influence of different seasons on the quality of baby spinach leaves during growing and postharvest storage. The study was initiated in early Nov. 2013 and culminated toward the end of Oct. 2014, then was repeated from Nov. 2014 until Oct. 2015. A $4 \times 5 \times 3$ factorial experiment was laid out in a randomized complete block design with four replicates per treatment. The treatments were arranged as follows. In autumn, winter, spring, and summer, leaves were kept up to $12 \mathrm{~d}$ at three different temperatures: 4, 10, and $20{ }^{\circ} \mathrm{C}$. Parameters recorded are weight loss, leaf length, total flavonoids, and antioxidant activity. Results of the study demonstrate that the level of antioxidants in winter remained stable during storage, specifically at $4{ }^{\circ} \mathrm{C}$, followed by autumn and spring. In contrast, the summer season reflected the worse potential of retaining a level of antioxidants compared with the other seasons. On day 12 , at a storage temperature of $4{ }^{\circ} \mathrm{C}$, winter maintained $0.55 \mathrm{mg} \cdot \mathrm{g}^{-1}$ dry weight (DW), whereas autumn, spring, and summer had $0.41,0.40$, and $0.11 \mathrm{mg} \cdot \mathrm{g}^{-1}$ DW, respectively. In conclusion, it is recommended that baby spinach growers consider winter, autumn, and spring for growing baby spinach to manage the quality favorably during the postharvest storage period in South Africa.
\end{abstract}

Spinach (Spinacia oleracea L.) is an annual, cool-season, and green leafy vegetable that in temperate areas can be grown yearround (Conte et al., 2008; Rodríguez-Hidalgo et al., 2010). Koike et al. (2011) reported that spinach can grow most rapidly in winter at 5 to $18^{\circ} \mathrm{C}$, although it can also withstand low temperatures of -9 to $-6{ }^{\circ} \mathrm{C}$ without severe injury. Thus, annual fluctuations in certain parameters such as radiation, temperature, rainfall, and other related environmental factors, as well as time of season, affect the growth and quality of spinach (Bergquist et al., 2005).

\footnotetext{
Received for publication 9 Nov. 2018. Accepted for publication 12 Feb. 2019.

This work was supported financially by the Gauteng Department of Agriculture and Rural Development (GUN no. 359000).

${ }^{1}$ Corresponding author. E-mail: mudaufn@unisa. ac.za.
}

Spinach leaves have been reported to contain high contents of bioactive compounds such as antioxidants (Cao et al., 1996), total phenolics (Wu et al., 2004), flavonoids, and vitamin C (Gil et al., 1999). However, postharvest conditions influence the composition of these compounds. Postharvest products are living materials (Pandjaitan et al., 2005), and therefore, several processing procedures may induce a stress reaction and thereby affect the quality of the product (Hodges and Toivonen, 2008). Undesirable results that may be caused by the postharvest factors are linked to loss of flavor and texture tissue decay (Varoquaux and Wiley, 1994), and development of an "off" odor (Allende et al., 2004), depending on the intensity of stress-induced postharvest factors.

Different seasons may influence differently the quality and shelf life of produce. However, relatively little has been published on the influence of season on the growth and quality of baby spinach postharvest (Bergquist et al., 2005, 2006; Howard et al., 2002). Therefore, the current investigation was conducted to evaluate the influence of different seasons on the growth productivity and postharvest quality of baby spinach leaves.

\section{Materials and Methods}

\section{Plant material and field experiment} design

The experiment was conducted at the Agricultural Research Council Vegetable and Ornamental Plant Institute situated about $25 \mathrm{~km}$ north of Pretoria on the KwaMhlanga Road (R573), Gauteng Province, South

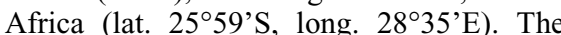
study began in early Nov. 2013 and culminated toward the end of Oct. 2014, then was repeated from Nov. 2014 until Oct. 2015. A $4 \times 5 \times 3$ factorial experiment was laid out in a randomized complete block design with four replicates per treatment. The treatments were arranged as follows - autumn, winter, spring, and summer-and leaves were kept up to $12 \mathrm{~d}$ at three different temperatures: 4 , 10 , and $20^{\circ} \mathrm{C}$. On the 4 Nov. 2013, 400 seeds of baby spinach, cv. Ohio (Hygrotech, Pretoria, South Africa), were sown in $2.2 \times$ $2.2 \mathrm{~m}^{2}$ plots with an interrow spacing of $200 \mathrm{~mm}$ and an intrarow spacing of $100 \mathrm{~mm}$. Seedlings were thinned after $12 \mathrm{~d}$ of sowing. The field soil conditions were light sandy clay soil, with a $\mathrm{pH}-\mathrm{KCI}$ ranging from 7.3-7.7; soil organic matter content ranged between 1.5 and $2.2 \%$. Plants were fertilized with a balanced nutrient solution that contained all nutrients as described by Nemadodzi (2014). Drip irrigation was applied for $2 \mathrm{~h} 30 \mathrm{~min} / \mathrm{d}$. Plants were harvested after $36 \mathrm{~d}$ of sowing and were transported immediately to the laboratory, where they were washed with running water, ventilated, and weighed before being stored at 4,10 , or $20{ }^{\circ} \mathrm{C}$ for $12 \mathrm{~d}$. Experiments were conducted in the summer, autumn, winter, and spring with the same experimental designed just described. In all seasons, experiments were repeated. Annual rainfall was $316.2 \mathrm{~mm}$ in 2014 (with an inclusion of Nov. and Dec. 2013) and $317.3 \mathrm{~mm}$ in 2015 (with an inclusion of Nov. 2014 and Dec. 2014). Temperature and rainfall were recorded for all seasons as shown in Table 1.

\section{Data collection}

The following data were collected: weight loss, leaf length, mineral and trace elements, total flavonoids, and antioxidant activity.

Weight loss. Baby spinach leaves were weighed using a digital electronic balance [model MK-500C; DENVER instrument ( $\pm 0.001 \mathrm{~g})$; Sigma-Aldrich, St. Louis, MO] at the beginning and end of each storage period. Data are expressed as percentage weight loss.

Leaf length. One parameter recorded during growing stages was leaf length. Fifteen random plants per season were measured after $21 \mathrm{~d}$ of sowing, until $35 \mathrm{~d}$ of sowing, 
with an interval of $7 \mathrm{~d}$. Plant leaf length was measured in centimeters using a Vernier caliper (Mitutoyo Corporation, Japan).

Mineral and trace elements. All mineral and trace elements were analyzed using a method described by van der Walt et al. (2009). All essential mineral (Mg, Ca, K, P, and $\mathrm{Na}$ ) and trace elements $(\mathrm{Mn}, \mathrm{Zn}, \mathrm{B}, \mathrm{Cu}$, and $\mathrm{Fe}$ ) were analyzed using a method described by van der Walt et al. (2009). A $100-\mathrm{mg}$ freeze-dried sample was weighed accurately and heated in $1 \mathrm{~mL}$ nitric acid (70\%) until clarity was achieved. After cooling, $3 \mathrm{~mL}$ water was added and heating resumed for a further $10 \mathrm{~min}$. Finally, the solution was cooled and deionized water was added until a volume of $10 \mathrm{~mL}$ was attained. The mineral concentrations of each sample were determined using an Agilent 7500c inductively coupled argon plasma mass spectrometer (ThermoFinnigan/FinniganMAT, San Jose, CA). Calibrations were performed using external standards prepared from a 1000 -ppm single stock solution made up of $2 \%$ nitric acid. External calibrations were run in the same analytical sequence as the samples.

Evaluation of total flavonoid content. Total flavonoids were measured using a modified calorimetric method described by
Yoo et al. (2008). Briefly, $1 \mathrm{~mL}$ of the extracts or standard solutions of catechin was added to a $10-\mathrm{mL}$ volumetric flask. Distilled water was added to make a volume of $5 \mathrm{~mL}$. At time zero, $0.3 \mathrm{~mL} 5 \%(\mathrm{w} / \mathrm{v})$ sodium nitrite was added to the flask. After 5 min, $0.6 \mathrm{~mL} \mathrm{10 \%} \mathrm{(w/v)} \mathrm{AlCl}_{3}$ was added and, after $6 \mathrm{~min}, 2 \mathrm{~mL} 1 \mathrm{M} \mathrm{NaOH}$ was also added to the mixture, followed by the addition of $2.1 \mathrm{~mL}$ distilled water. Absorbance was measured against the blank at $510 \mathrm{~nm}$ after $15 \mathrm{~min}$. A standard curve was prepared using different concentrations of catechin. The flavonoid content is expressed as milligrams catechin equivalents per $100 \mathrm{~g} \mathrm{DW}$.

Table 1. Maximum $\left(T_{\max }\right)$ and minimum $\left(T_{\min }\right)$ temperatures and rainfall during field cultivation of baby spinach at different growing seasons.

\begin{tabular}{|c|c|c|c|c|c|c|c|c|}
\hline \multirow{2}{*}{$\begin{array}{l}\text { Season/mo } \\
\text { Summer }\end{array}$} & \multicolumn{2}{|c|}{ Yr } & \multicolumn{2}{|c|}{$T_{\max }\left({ }^{\circ} \mathrm{C}\right)$} & \multicolumn{2}{|c|}{$T_{\min }\left({ }^{\circ} \mathrm{C}\right)$} & \multicolumn{2}{|c|}{ Rainfall (mm) } \\
\hline & & & & & & & & \\
\hline January & 2014 & 2015 & 31.1 & 29.5 & 16.8 & 16 & 75.4 & 40.8 \\
\hline February & 2014 & 2015 & 30.3 & 30.4 & 17 & 15 & 111.2 & 44.2 \\
\hline March & 2014 & 2015 & 26.9 & 28.3 & 15.6 & 13.5 & 247.4 & 44.2 \\
\hline April & 2014 & 2015 & 25.9 & 25.9 & 9 & 9.6 & 22.2 & 15.2 \\
\hline May & 2014 & 2015 & 24.2 & 26.1 & 3.9 & 3.4 & 0.6 & 0.4 \\
\hline July & 2014 & 2015 & 20.3 & 20.8 & -1.5 & 0.9 & 0 & 1.8 \\
\hline August & 2014 & 2015 & 22.6 & 25.9 & 2.6 & 3.3 & 0.2 & 0 \\
\hline \multicolumn{9}{|l|}{ Spring } \\
\hline September & 2014 & 2015 & 27.9 & 26.4 & 7 & 9.8 & 1.2 & 27.4 \\
\hline October & 2014 & 2015 & 27.9 & 30.1 & 10.5 & 13.1 & 31.2 & 41.2 \\
\hline November & 2013 & 2014 & 30 & 26 & 14.5 & 13.1 & 160.6 & 154 \\
\hline
\end{tabular}

Data for station (514408AX) Bronkhorstspruit was measured at 8:00 AM (GMT+2) and was provided by the South African Weather Service.
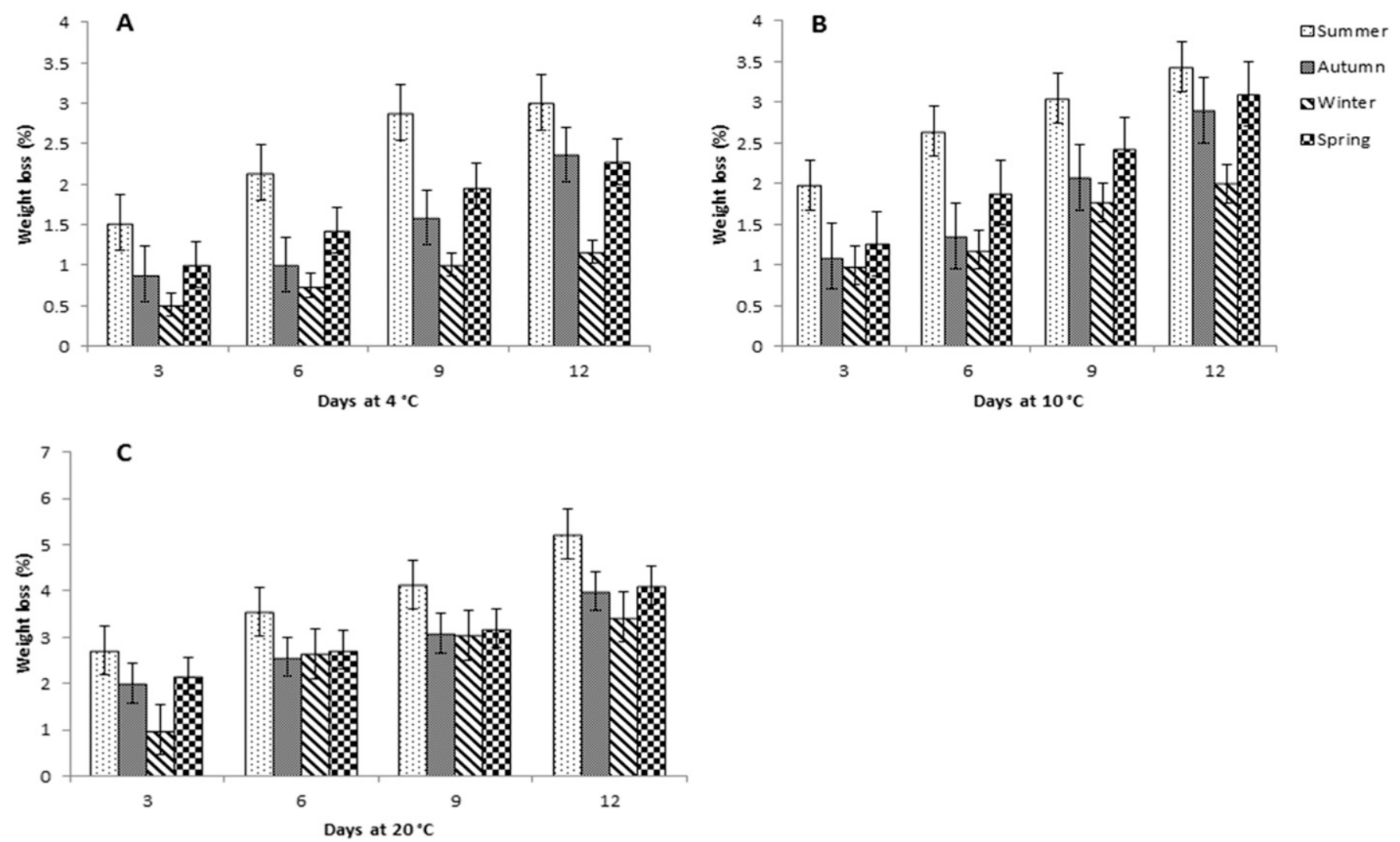

Fig. 1. Percentage cumulative weight loss of baby spinach grown during summer, autumn, winter, and spring; and stored at $4{ }^{\circ} \mathrm{C}(\mathbf{A}), 10^{\circ} \mathrm{C}(\mathbf{B})$, and $20{ }^{\circ} \mathrm{C}(\mathbf{C})$ for $12 \mathrm{~d}$. Vertical bars indicate SE. 
Determination of total antioxidant activity (TAA). Total antioxidant activity (by free radical scavenging) of the extracts was determined using the Trolox Equivalent Antioxidant Capacity assay as described by Awika and Rooney (2004). Briefly, 2,2' -azinobis(3-ethylbenzothiazoline-6-sulphonic acid) $\left(\mathrm{ABTS}^{+}\right)$was produced by mixing equal volumes of $8 \mathrm{~mm}$ ABTS with $3 \mathrm{~mm}$ potassium persulfate. These were prepared in distilled water and were allowed to react in the dark for at least $12 \mathrm{~h}$ at room temperature before use. The $\mathrm{ABTS}^{+}$solution was diluted with a phosphate buffer solution ( $\mathrm{pH} 7.4$ ) mixed with $0.2 \mathrm{M} \mathrm{NaH}_{2} \mathrm{PO}_{4}$ and $150 \mathrm{~mm} \mathrm{NaCl}$ in $1 \mathrm{~L}$ distilled water, with $\mathrm{pH}$ adjustment using $\mathrm{NaOH}$ when necessary. A freshly prepared solution was used for each analysis. The ABTS $^{+}$solution $(2900 \mu \mathrm{L})$ was added to the methanol extracts $(100 \mu \mathrm{L})$ of Trolox in a test tube and mixed. Absorbency readings (at 734

Table 2. Leaf length of baby spinach measured during growing summer, autumn, winter, and spring seasons.

\begin{tabular}{lccc}
\hline & \multicolumn{3}{c}{ Leaf length $(\mathrm{cm})^{\mathrm{z}}$} \\
\cline { 2 - 4 } Growing season & $21 \mathrm{DAS}$ & $28 \mathrm{DAS}$ & $35 \mathrm{DAS}$ \\
\hline Autumn & $5.5 \mathrm{a}$ & $6.7 \mathrm{a}$ & $7.3 \mathrm{a}$ \\
Winter & $2.6 \mathrm{~b}$ & $3.5 \mathrm{~b}$ & $5.4 \mathrm{~b}$ \\
Spring & $6.4 \mathrm{a}$ & $7.2 \mathrm{a}$ & $7.0 \mathrm{a}$ \\
Summer & $3.1 \mathrm{~b}$ & $4.3 \mathrm{~b}$ & $4.2 \mathrm{~b}$ \\
\hline
\end{tabular}

${ }^{\mathrm{z}}$ Means in rows followed by different letters are significantly different at $P \leq 0.05$.

$\mathrm{DAS}=$ days after sowing. $\mathrm{nm}$ ) were taken after $30 \mathrm{~min}$ (for the samples) and $15 \mathrm{~min}$ (for the standard) of the initial mixing of the samples and standard, respectively. The results were expressed as micromolar Trolox equivalents per gram of sample on a DW basis.

\section{Statistical analysis}

The trials were repeated twice. Because there was no significant difference between trials, data were pooled and subjected to analysis of variance using SAS version 9.4. Means were separated with the Tukey's honestly significant difference.

\section{Results and Discussion}

There is a lack of literature demonstrating the influence of season on growth, productivity, and postharvest of baby spinach. The relations are critical in baby spinach industry because periodic harvesting generally imposes significant perturbation of plant growth and development.

In our study, weight loss gradually increased as storage duration and temperature increased. When spinach samples were stored at $4{ }^{\circ} \mathrm{C}$, the greatest weight loss was observed in spinach grown during the summer season, with a weight loss of $3.01 \%$, followed by spinach grown in autumn $(2.36 \%)$, spring $(2.28 \%)$, and winter (1.16\%) (Fig. 1A).

The least weight loss was observed in the plants grown in winter $(0.51 \%)$ and autumn
$(0.89 \%)$ when stored at $4{ }^{\circ} \mathrm{C}$. When baby spinach leaf samples were stored at $10{ }^{\circ} \mathrm{C}$, weight loss ranged between $0.99 \%$ and $3.43 \%$ in plants grown during the winter and summer seasons, respectively (Fig. 1B). Weight loss was not significantly different $(P>0.05)$ between plants grown in autumn and winter, whereas there was significant difference $(P<0.05)$ in weight loss of plants grown in the summer and winter seasons when stored at $10{ }^{\circ} \mathrm{C}$.

A storage temperature of $20^{\circ} \mathrm{C}$ resulted in greater weight loss compared with 4 and $10{ }^{\circ} \mathrm{C}$, with the greatest weight loss $(5.23 \%)$ seen in plants grown during the summer (Fig. 1C). In general, at all storage temperatures, plants grown during the summer season had greater weight loss, whereas those grown during the winter season had lower weight loss. Climatic conditions also influence the composition of plant tissues during growth and development processes. Lee and Kader (2000) highlighted that total heat, extent of low temperature, and rainfall occurrence are the most important factors in determining growth rate and chemical composition of horticultural crops. Thus, high and low temperatures retarded growth and development of spinach leaves. This was evident in the leaf length observed in spinach grown during the summer and winter seasons. Furthermore, Bassioni et al. (1980) reported that the increase in petiole length could be the result of an accumulation of greater nitrate
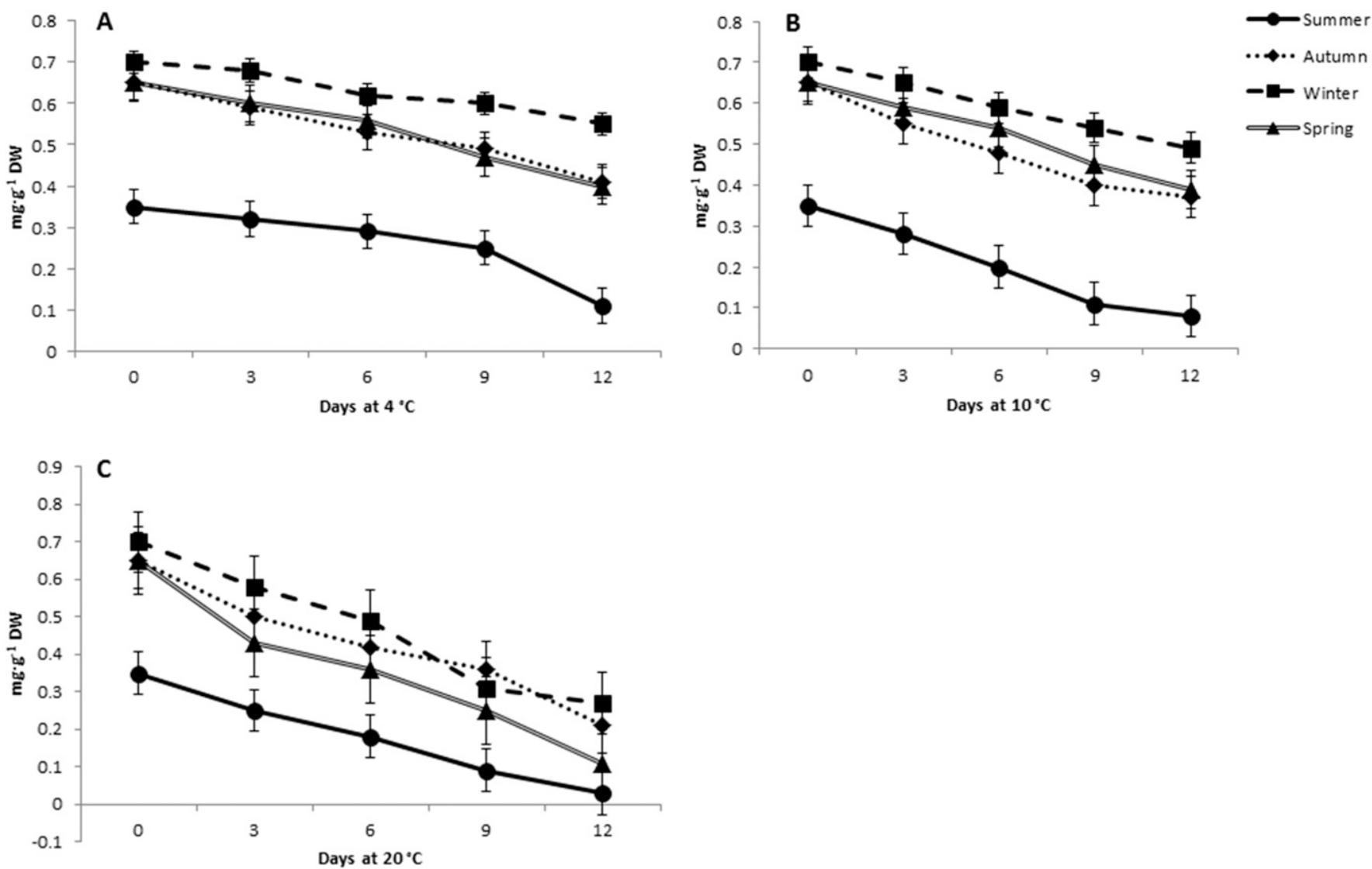

Fig. 2. Total antioxidants of baby spinach grown during different seasons—namely, summer, autumn, winter, and spring-and stored at $4{ }^{\circ} \mathrm{C}(\mathbf{A}), 10^{\circ} \mathrm{C}(\mathbf{B})$, and $20{ }^{\circ} \mathrm{C}(\mathbf{C})$ for $12 \mathrm{~d}$. Vertical bars indicate $\mathrm{SE}$. 
concentrations in spring petioles than in winter petioles.

There was no significant interaction between seasons and minerals when stored at 4 , 10 , and $20^{\circ} \mathrm{C}$ for $12 \mathrm{~d}$. Despite the lack of interaction, at harvest, $\mathrm{Mg}, \mathrm{Fe}$, and $\mathrm{Zn}$ levels were predominantly greater in plants grown during the spring and autumn seasons (data not shown).

Baby spinach leaves grown in autumn yielded longer leaves than those grown in winter and summer. After $21 \mathrm{~d}$ of sowing, spring plants had longer leaves $(6.4 \mathrm{~cm})$ than other plants grown during autumn $(5.5 \mathrm{~cm})$, summer $(3.1 \mathrm{~cm})$, and winter $(2.6 \mathrm{~cm})$, as shown in Table 2. Winter plants were found to increase in length with time, despite having a shorter leaf length, unlike summer plants, which were found to have stagnant leaf length, particularly after 28 and $35 \mathrm{~d}$ of sowing. Plants grown during autumn were significantly longer than those grown during the winter and summer seasons.

The effect of growing season on the total antioxidant activity in spinach leaves was very noticeable at harvest. The level of TAA at harvest ranged between 0.35 to $0.70 \mathrm{mg} \cdot \mathrm{g}^{-1}$ DW (Fig. 2A-C) and varied significantly between the growing seasons. The greatest TAA level was seen in spinach grown during the winter season; the least level was observed in spinach grown in summer. Interestingly, spin- ach grown during the autumn and spring seasons showed a similar level of TAA $(0.65$ $\left.\mathrm{mg} \cdot \mathrm{g}^{-1} \mathrm{DW}\right)$. As it has been observed in a previous study by Mudau et al. (2015), spinach samples stored at $4{ }^{\circ} \mathrm{C}$ showed the greatest capacity in retaining the best level of antioxidant activity, followed by samples stored at 10 and $20^{\circ} \mathrm{C}$ (Fig. 2A-C). After $6 \mathrm{~d}$ of storage, the greatest level of TAA was observed in spinach grown during the winter season $\left(0.62 \mathrm{mg} \cdot \mathrm{g}^{-1}\right.$ DW) when stored at $4{ }^{\circ} \mathrm{C}$, followed by samples grown during the spring $\left(0.56 \mathrm{mg} \cdot \mathrm{g}^{-1} \mathrm{DW}\right)$, autumn (0.53 $\left.\mathrm{mg} \cdot \mathrm{g}^{-1} \mathrm{DW}\right)$, and summer $\left(0.29 \mathrm{mg} \cdot \mathrm{g}^{-1} \mathrm{DW}\right)$ seasons. As the experiment progressed, the TAA level was significantly greater in baby spinach grown during winter than in that grown during the summer season, whereas those grown in autumn and spring did not show a significant difference $(P>0.05)$. On day 12 of storage, spinach grown in winter and stored at $10{ }^{\circ} \mathrm{C}$ had a greater TAA content $\left(0.49 \mathrm{mg} \cdot \mathrm{g}^{-1} \mathrm{DW}\right)$ than that grown during the autumn $\left(0.41 \mathrm{mg} \cdot \mathrm{g}^{-1}\right.$ DW), spring ( $\left.0.40 \mathrm{mg} \cdot \mathrm{g}^{-1} \mathrm{DW}\right)$, and summer (0.11 $\left.\mathrm{mg} \cdot \mathrm{g}^{-1} \mathrm{DW}\right)$ seasons when stored at $4{ }^{\circ} \mathrm{C}$. The least pronounced TAA content $\left(0.03 \mathrm{mg} \cdot \mathrm{g}^{-1} \mathrm{DW}\right)$ was observed in spinach grown in summer and stored at $20^{\circ} \mathrm{C}$.

The results on the effect of growing season together with storage temperature on the flavonoids in the spinach revealed a trend similar to that of the TAA findings. The greatest flavonoid content, at harvest, was observed in spinach grown in the winter (25.4 $\left.\mathrm{mg} \cdot \mathrm{g}^{-1} \mathrm{DW}\right)$, followed by spring (23.34 $\left.\mathrm{mg} \cdot \mathrm{g}^{-1} \mathrm{DW}\right)$, autumn $\left(22.6 \mathrm{mg} \cdot \mathrm{g}^{-1}\right.$ DW), and summer (19.95 mg. $\left.{ }^{-1} \mathrm{DW}\right)$ seasons (Fig. 3A-C). Flavonoids in spinach grown in the autumn and spring seasons showed no significant difference $(P>0.05)$. However, flavonoids in spinach grown during the winter season were significantly greater than those grown during the summer season throughout the storage duration. After $12 \mathrm{~d}$ of storage, the least flavonoid content was observed in spinach grown in summer (6.23 mg. $\left.{ }^{-1} \mathrm{DW}\right)$ and autumn (7.62 $\mathrm{mg} \cdot \mathrm{g}^{-1} \mathrm{DW}$ ) when stored at $20^{\circ} \mathrm{C}$. Mode of antioxidant action fully depends on the plant's growth and developmental stage, which together are affected by the growing season. The current findings differ slightly from those reported by Howard et al. (2002), who observed that spinach grown during the spring season had greater antioxidant activity, followed by fall (autumn), whereas in the current study, spinach grown in winter had greater antioxidant activity, followed by spinach grown in the spring and autumn seasons. Kitabayashi et al. (1995) found that rutin in the buckwheat was significantly influenced by seasonal variation.

Current findings concur with the finding reported by Howard et al. (2002), who reported
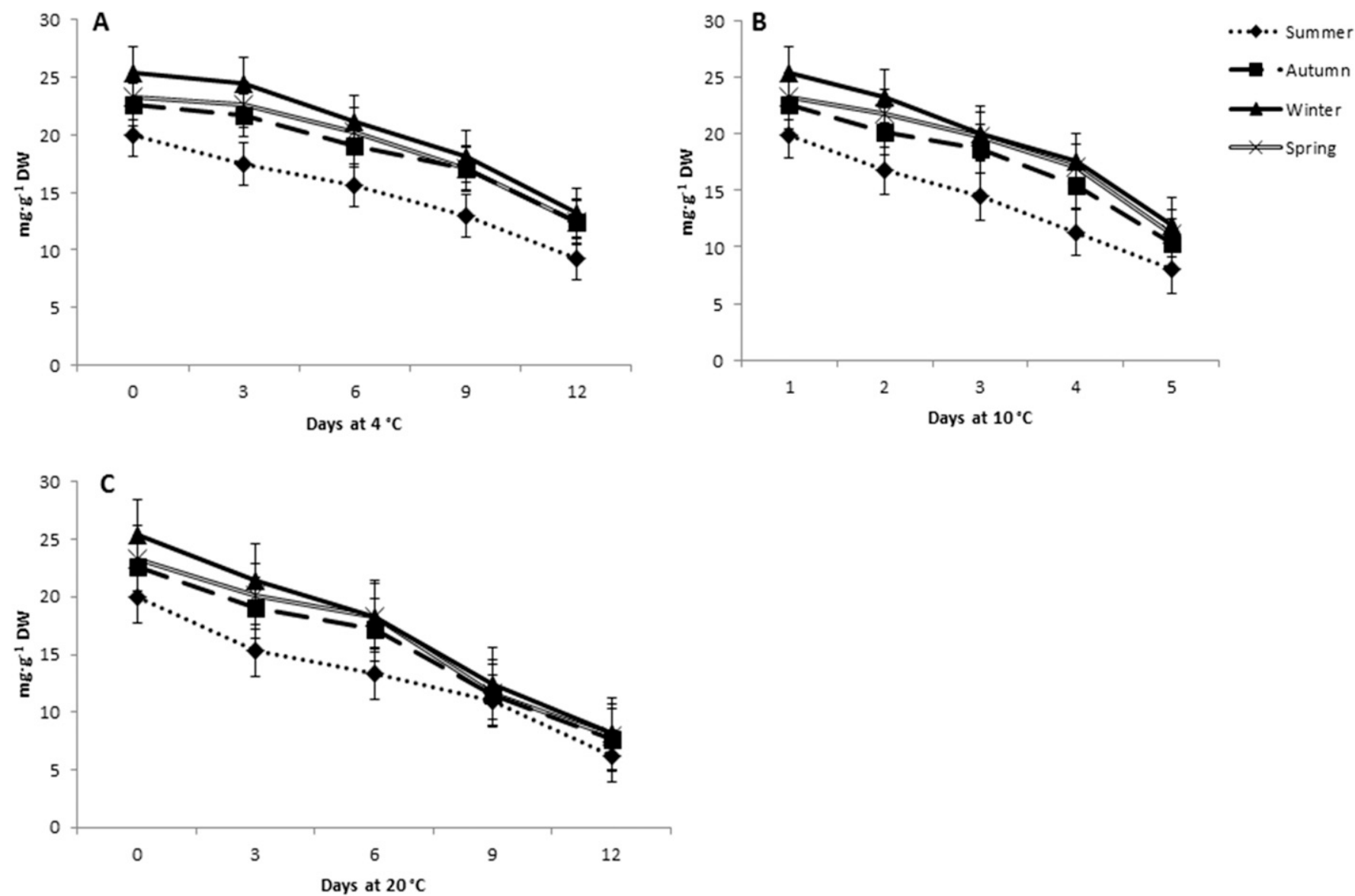

Fig. 3. Total flavonoids of baby spinach grown in four different seasons—-summer, autumn, winter, and spring — and stored at $4{ }^{\circ} \mathrm{C}(\mathbf{A}), 10{ }^{\circ} \mathrm{C}(\mathbf{B})$, and $20^{\circ} \mathrm{C}(\mathbf{C})$ for $12 \mathrm{~d}$. Vertical bars indicate SE. 
a positive linear relationship between antioxidant and flavonoid content during storage of spinach in the fall and spring growing seasons. Similarly, Bergquist et al. (2005) reported that the flavonoid content was greatest in late winter than in summer, when the least flavonoid content was observed. In contrast, Hall et al. (2013) reported that the extended shelf life in perennial wall rockets leaves could be achieved by growing the crop during the summer, followed by spring and winter.

In conclusion, spinach grown during the winter and spring seasons had greater levels of total antioxidant activity and flavonoids. Although it has been reported that spinach is a year-round crop, it is very important to consider favorable growing seasons, because spinach may not respond positively to growth during the summer season. However, there was no commercial significance, although winter and spring yielded more antioxidants and flavonoids on a DW basis.

\section{Literature Cited}

Allende, A., L. Luo, J.L. McEvoy, F. Artés, and C.Y. Wang. 2004. Microbial and quality changes in minimally processed baby spinach leaves stored under super atmospheric oxygen and modified atmosphere conditions. Postharvest Biol. Technol. 33:51-59.

Awika, J.M. and L.W. Rooney. 2004. Sorghum photochemical and their stability in sunflower oil and emulsion. Food Chem. 64:323-329.

Bassioni, N., N. Allam, and Y. Abaido. 1980. Effect of nitrogen fertilization and season of growth on nitrate content of spinach plants (Spinacia oleracea L.). Z. Pflanzenernährung Bodenkunde. 143:652-658.

Bergquist, S.A.M., U.E. Gertsson, P. Knuthsen, and M.E. Olsson. 2005. Flavonoids in baby spinach (Spinacia oleracea L.): Changes during plant growth and storage. J. Agr. Food Chem. 53:9459-9464.

Bergquist, S.A.M., U.E. Gertsson, and M.E. Olsson. 2006. Influence growth stage and postharvest storage on ascorbic acid and carotenoid content and visual quality of baby spinach (Spinacia oleracea L.). J. Sci. Food Agr. 86:346-355.

Cao, G., E. Sofic, and R.L. Prior. 1996. Antioxidant capacity of tea and common vegetables. J. Agr. Food Chem. 44:3426-3431.

Conte, A., G. Conversa, C. Scrocco, I. Brescia, J. Laverse, A. Elia, and M.A. Del Nobile. 2008. Influence of growing periods on the quality of baby spinach leaves at harvest and during storage as minimally processed produce. Postharvest Biol. Technol. 50:190-196.

Gil, M.I., S. Hernández, M.A. Conesa, and F. Artés. 1999. Keeping quality in minimally processed tomato slices by chemical treatments. Acta Hort. 4:274-279.

Hall, M.K.D., J.J. Jobling, and G.S. Rogers. 2013. Influence of storage temperature on the seasonal shelf life of perennial wall rocket and annual garden rocket. Intl. J. Veg. Sci. 19:8395.

Hodges, D.M. and P.M. Toivonen. 2008. Quality of fresh-cut fruits and vegetables as affected by exposure to abiotic stress. Postharvest Biol. Technol. 48:155-162.

Howard, L.R., N. Pandjaitan, T. Morelock, and M.I. Gil. 2002. Antioxidant capacity and phenolic content of spinach as affected by genetics and growing season. J. Agr. Food Chem. 50:5891-5896.

Kitabayashi, H., A. Ujihara, T. Hirose, and M. Minami. 1995. Varietal differences and heritability for rutin content in common buckwheat, Fagopyrum esculentum Moench. Japan. J. Breeding. 45:75-79.

Koike, S.T., M. Cahn, M. Cantwell, S. Fennimore, M. LeStrange, E. Natwick, R.F. Smith, and E. Takele. 2011. Spinach production in California. University of California Agr. Nat. Resources. Publ. 7212.
Lee, S.K. and A.A. Kader. 2000. Preharvest and postharvest factors influencing vitamin $\mathrm{C}$ content of horticultural crops. Postharvest Biol. Technol. 20:207-220.

Mudau, A.R., M. Nkomo, P. Soundy, H.T. Araya, W. Ngezimana, and F.N. Mudau. 2015. Influence of post-harvest storage temperature and duration on quality of baby spinach. HortTechnology 25:665-670.

Nemadodzi, L.E. 2014. Growth and development of baby spinach (Spinacia oleraceae L.) in response to mineral nutrition. University of South Africa, MS Diss.

Pandjaitan, N., L.R. Howard, T. Morelock, and M.I. Gil. 2005. Antioxidant capacity and phenolic content of spinach as affected by genetics and maturation. J. Agr. Food Chem. 53:86188623.

Rodríguez-Hidalgo, S., F. Artés-Hernández, P.A. Gómez, J.A. Fernández, and F. Artés. 2010. Quality of fresh-cut baby spinach grown under a floating trays system as affected by nitrogen fertilisation and innovative packaging treatments. J. Sci. Food Agr. 90:10891097.

van der Walt, A.M., D.T. Loots, M.I.M. Ibrahim, and C. C. Bezuidenhout. 2009. Minerals, trace elements and antioxidant phytochemicals in wild African dark-green leafy vegetables (morogo). S. Afr. J. Sci. 105:11-12.

Varoquaux, P. and R.C. Wiley. 1994. Biological and biochemical changes in minimally processed refrigerated fruits and vegetables, $\mathrm{p}$. 226-268. In: R.C. Wiley (ed.). Minimally processed refrigerated fruits and vegetables. Springer, Boston, MA

Wu, X., L. Gu, J. Holden, D.B. Haytowitz, S.E. Gebhardt, G. Beecher, and R.L. Prior. 2004. Development of a database for total antioxidant capacity in foods: A preliminary study. J. Food Compos. Anal. 17:407-422.

Yoo, K.M., C.H. Lee, H. Lee, B. Moon, and C.Y. Lee. 2008. Relative antioxidant and cytoprotective activities of common herbs. Food Chem. 106:929-936. 